\title{
Peningkatan Teacher Skills melalui Supervisi Klinis dengan Pendekatan Kooperatif Learning
}

\author{
${ }^{1}$ Anwar Sewang, ${ }^{2}$ Mustapa T \\ ${ }^{1}$ STAIN Majene, West Sulawesi, Indonesia \\ IAI DDI Polewali Mandar, West Sulawesi, Indonesia \\ Email: sewanganwar@yahoo.com
}

\begin{abstract}
Abstrak
Penelitian ini adalah Penelitian Tindakan Sekolah. Masalah dalam penelitian ini adalah guru-guru di SMA negeri 4 Polewali yang belum menerapkan pembelajaran kooperaif dalam pembelajaran di kelas. Subyek dalam penelitian adalah guru-guru di SMA Negeri 4 Polewali sebanyak 15 orang. Penelitian dilakukan dalam dua siklus yang terdiri dari Perencanaan, Pelaksanaan, Pengamatan, Refleksi. Hasil penelitian menunjukkan bahwa Supervisi klinis dapat meningkatkan kemampuan guru menerapkan model pembelajaran kooperatif di SMA negeri 4 Polewali Kabupaten Polewali Mandar semester II tahun pelajaran 2019/2020.
\end{abstract}

\section{Kata kunci: supervisi klinis, kooperatif}

\section{PENDAHULUAN}

Guru-guru di SMA negeri 4 Polewali adalah peralihan dari SMA PGRI Polewali yang telah ditutup operasionalnya. Sebagai guru sekolah swasta tentu banyak mengalami perbedaan dengan sekolah negeri salah satunya adalah kemampuan guru dalam menyusun Rencana pelaksanaan pembelajaran (RPP). Pembelajaran yang bermutu tergambar dari Rencana pelaksanaan pembelajaran (RPP) yang bermutu pula. Salah satu indikator pembelajaran yang bermutu dilihat dari RPP adalah penggunaan metode mengajar yang sesuai. Kondisi di SMA negeri 4 Polewali masih belum dilakukan dengan maksimal oleh guru, dan mereka belum banyak kreatif menggunakan model-model pembelajaran dengan pendekatan yang baru. Berdasarkan hasil supervisi penulis di SMA Negeri 4 Polewali Kabupaten Polewali Mandar, ternyata sebagian besar guru masih melaksanakan pembelajaran yang tradisional, di mana guru dalam melaksanakan pembelajaran tanpa menggunakan RPP yang dibuat sendiri, mereka cenderung menggunakan RPP cetakan yang ada dan belum melaksanakan pembelajaran kooperatif. Guru masih melaksanakan pembelajaran dengan metode ceramah murni belum bervariasi, bahkan masih ada yang belum menggunakan alat peraga, dan tampaknya guru masih sebagai penyampai materi bentuk klasikal, belum banyak melakukan pembelajaran yang kreatif model kooperatif, yang dapat melatih mandiri dan tanggungjawab para peserta didik. Hal ini dapat dilihat dari hasil supervisi yang telah dilaksanakan oleh penulis dari sejumlah guru di SMA Negeri 4 Polewali Kabupaten Polewali Mandar sebanyak 15 orang, ternyata rata-rata guru belum mampu melaksanakan pembelajaran berpusat kooperatif secara maksimal yaitu 13 orang 
guru $(86,67 \%)$. Dari hasil supervisi rutin dapat dilihat secara nyata bahwa guru masih melaksanakan pembelajaran yang biasa-biasa saja. Pembelajaran yang dilakukan hanya menggunakan metode ceramah tanpa ada variasi dan kurang memanfaatkan peluang, membentuk kelompok-kelompok kecil di kelasnya. Kegiatan pembelajaran di SMA 4 Polewali Kabupaten Polewali Mandar masih tergolong rendah dan kemampuan guru dalam mengajar belum berpusat pada model pembelajaran kooperatif secara optimal. Terdapat bukti prestasi para siswa masih rendah belum sesuai dengan harapan lembaga sekolah orang tua dan masyarakat. Kondisi ini penulis sebagai Kepala Sekolah berupaya agar semua guru dalam melaksanakan pembelajaran berpusat dengan model pembelajaran kooperatif. Apabila semua guru dalam melaksanakan tugasnya setiap hari mengajar dengan berpusat kooperatif di kelasnya, maka dapat dikatakan, bahwa hasil dari proses pembelajaran itu akan tercapai memuaskan, yang pada gilirannya akan meningkatkan prestasi belajar para peserta didiknya.

Kemampuan guru dalam melaksanakan model pembelajaran kooperatif melalui supervisi klinis oleh Kepala Sekolah, dengan bimbingan arahan kesadaran tinggi diharapkan para guru dapat melakukan pembelajaran bermutu, sehingga memengaruhi positif terhadap perilaku peserta didik dan menambah kemajuan prestasi belajar mereka. Kemampuan dan keterampilan para guru dalam menyusun Rencana Pelaksanaan Pembelajaran Model Kooperatif yang baik, yang selanjutnya proses pembelajaran akan dapat tepat sasaran, dan target materi dalam Standar Kompetensi dan Kompetensi Dasar dapat dicapai. Selain itu juga kreatif membentuk kelompok-kelompok kecil dalam pembelajaran yang dapat menumbuhkan motivasi dan semangat belajar anak. Untuk selanjutnya mampu menumbuhkan kreatifitas peserta didik serta berikutnya pembelajaran dapat bermakna. Hal ini akan mewarnai kegiatan belajar dalam meningkatkan prestasinya sehari-hari. Dengan demikian kemampuan dan keterampilan guru perlu dibimbing yaitu mewujudkan model pembelajaran kooperatif yang sesuai dengan visi, misi sekolah yang telah dirumuskan. Pelaksanaan supervisi yang dilakukan penulis berupaya mengubah kegiatan mengajar guru yang lebih baik dengan menggunakan instrumen khusus tentang pembelajaran di kelasnya. Maka sasaran supervisi mampu mengubah perilaku guru untuk lebih kreatif dalam melaksanakan tugas mengajar yang menarik dan disukai peserta didik. Oleh karena itu proses pembelajaran diharapkan selalu terlaksana dengan menyenangkan, para peserta didik dapat memusatkan perhatiannya untuk belajar bersama teman-temannya.

Penulis berupaya menambah frekuwensi supervisi klinis dan memaksimalkan pembinaan dan bimbingan serta tindak lanjut. Upaya ingin meningkatkan prestasi dan kemajuan belajar, agar terdapat peningkatan prestasi belajar siswa. Selain itu penulis bekerja sama dengan wakil kepala sekolah dalam melaksanakan supervisi klinis tersebut, dengan maksud agar terjalin kolaborasi positif antara guru dan kepala sekolah, yang pada gilirannya kondisi kelas masing-masing dalam sekolah itu dapat nyaman, melaksanakan Pembelajaran Berpusat Kooperatif dengan baik. Keberhasilan proses pembelajaran dapat ditentukan oleh sering dan tidaknya supervisi yang dilakukan oleh kepala sekolah maupun pengawas sekolah, karena guru akan termotivasi kemampuannya dalam melaksanakan tugas manakala ada respon baik antara kepala sekolah, guru maupun pengawas sekolah. Antara guru, kepala sekolah, dan pengawas sekolah, merupakan komponen utama yang harus memberdayakan diri agar mampu memajukan prestasi belajar peserta didik, maka 
dalam hal ini penulis sebagai Kepala Sekolah berupaya melakukan supervisi klinis. Dalam penelitian ini ada dua masalah pokok yang akan diteliti yaitu pertama masalah kegiatan guru mengajar berpusat Kooperatif dan yang kedua kemampuan guru dalam menyusun RPP yang sesuai dengan standar proses menurut Permendiknas No 41 tahun 2007. Diharapkan para guru mampu melaksanakan pembelajaran yang berpusat kooperatif secara maksimal. Pembelajaran yang berlangsung dengan persiapan yang matang dan pelaksanaan dengan pendekatan Pembelajaran Model Kooperatif, akan berdampak positif terhadap prestasi belajar yang dicapai siswa. Peserta didik akan terpacu dan termotivasi untuk selalu belajar dan memperhatikan gurunya secara kelompok, karena dalam Pembelajaran Kooperatif akan selalu terlihat pemberian dorongan dan penghargaan kepada peserta didik secara merata, dengan demikian mereka diberdayakan agar merasa butuh dan merasa senang dalam melakukan kegiatan belajarnya. Maka guru yang utama adalah perlu ditingkatkan kemampuannya dalam melakukan tugas di kalasnya. Kegiatan supervisi klinis yang dilakukan sebagai penulis Kepala Sekolah akan berupaya memengaruhi guru selalu termotivasi, dan mereka agar selalu merasa sebagai agen pembelajaran yang sesuai dengan ketentuan. Maka penulis sebagai kepala Sekolah melakukan supervisi klinis dengan terprogram dan selalu berupaya meningkatkan kemampuan guru untuk melaksanakan pembelajaran dengan tertib dan baik. Apabila supervisi sudah dilaksanakan secara rutin, terprogram dan berkelanjutan sesuai dengan prosedur ketentuan yang ada, maka dapat diharapkan guru lebih mampu untuk melaksanakan pembelajaran Model Kooperatif yang baik berkualitas serta mampu mengubah perilaku peserta didik untuk lebih aktif belajar, yang pada gilirannya mampu mencapai kemajuan prestasi belajar yang lebih baik. Untuk memecahkan masalah yang ada di SMA negeri 4 Polewali Kabupaten Polewali Mandar, perlu adanya tindakan khusus yang dilakukan oleh Kepala Sekolah, yaitu; Upaya peningkatan kemampuan guru di SMA negeri 4 Polewali dalam pembelajaran berpusat kooperatif melalui supervisi klinis Semester II Tahun Pelajaran 2019/2020. Tindakan tersebut dilakukan melalui supervisi klinis secara maksimal dengan tahapan yang pertama yaitu melaksanakan supervisi klinis secara kelompok dan yang kedua melaksanakan supervisi klinis secara individu di dalam kelas masing - masing guru. Dalam hal ini penulis sebagai Kepala Sekolah ingin meningkatkan keterampilan dan kemampuan guru dalam melaksanakan pembelajaran berpusat kooperatif. Termasuk kemampuan Guru dalam penyusunan Rencana Pelaksanaan Pembelajaran yang matang dengan sarana dan alat peraga yang bervariasi, maupun peralatan dalam proses pembelajaran yang menarik perhatian peserta didik. Pemilikan RPP yang baik bagi guru juga akan memengaruhi lancarnya penyajian pembelajaran di kelasnya. Meskipun pembelajaran kooperatif bukan satu-satunya solusi terhadap peningkatan kualitas pembelajaran, namun hal ini merupakan salah satu upaya dalam meningkatkan kualitas pembelajaran. Kondisi di SMA negeri 4 Polewali Kabupaten Polewali Mandar yang guru-gurunya masih membuat RPP dengan model pembelajaran yang masih menggunakan model ceramah dan tanya jawab merupakan permasalahan klinis. 


\section{KAJIAN TEORI}

\section{Kemampuan Melaksanakan Pembelajaran Berpusat Kooperatif.}

\section{a) Hakikat Kemampuan}

Seorang guru yang profesional diharapkan memiliki kemampuan dan keterampilan untuk menyusun Rencana Pelaksanaan Pembelajaran sebagai bukti yang harus dijalani dalam melaksanakan pembelajaran sehari-hari di kelasnya.

Proses pembelajaran akan berhasil dengan maksimal manakala diawali dari penyusunan Rencana Pelaksanaan Pembelajaran (RPP) yang tepat sesuai Standar Kompetensi (SK) dan Kompetensi Dasar (KD) dalam jadwal yang telah ditentukan, dan RPP ini disusun oleh guru mata pelajaran itu sendiri, merupakan perangkat yang penting dalam sasaran mutu pembelajaran.

Dalam penelitian ini kemampuan yang dimaksud adalah kompetensi atau potensi yang dinyatakan dalam perilaku, yang dimiliki oleh seorang guru untuk menyusun Rencana Pelaksanaan Pembelajaran. Menurut Kamus Umum Bahasa Indonesia WJS. Purwadarminto, bahwa kompetensi berarti kewenangan/kekuasaan untuk menentukan atau memutuskan sesuatu hal. Istilah kompetensi memiliki banyak makna sebagai mana penjelasan berikut ini ;

Descriptive of qualitative natur or teacher behavior appears to be enti rely meaningful (Broke and Stone, 1975 dalam Nurtain, 1989) bahwa kompetensi merupakan gambaran hakikat kualitatif dari perilaku guru yang tampak dan sangat berarti.

Adapun kompetensi guru (teacher competensy) the ability of a teacher to responsibility perform has or her duties appropriately, merupakan kemampuan seseorang guru dalam melaksanakan kewajiban-kewajiban secara bertanggungjawab dan layak.

Dari gambaran pengertian tersebut, dapat disimpulkan bahwa kompetensi merupakan kemampuan dan kewenangan seorang guru dalam melaksanakan profesi keguruannya dan dinyatakan dalam kinerjanya.

\section{b. Hakikat Pembelajaran}

Pelaksanaan pembelajaran merupakan proses inti dari proses pendidikan secara keseluruhan dengan guru sebagai pemegang peranan yang utama. Peristiwa pembelajaran banyak berakar pada berbagai pandangan dan konsep, oleh karena itu, perwujudan pembelajaran dapat terjadi dalam berbagai model. Menurut Moh. User Usman (1995:4) dalam bukunya Menjadi guru Profesional, Proses belajar - mengajar adalah suatu proses yang mengandung serangkaian perbuatan guru dan siswa atas dasar dukungan timbal balik yang berlangsung dalam situasi edukatif untuk mencapai tujuan tertentu. Interaksi atau hubungan timbal balik antara guru dan siswa merupakan syarat utama bagi berlangsungnya proses pembelajaran. Interaksi dalam peristiwa pembelajaran mempunyai arti yang lebih luas, tidak sekedar hubungan antara guru dan siswa, tetapi hubungan yang bersifat interaktif edukatif.

\section{c. Hakikat Model Pembelajaran Kooperatif}

Salah satu model pembelajaran yang dapat bermakna bagi siswa adalah model belajar kelompok kecil yang sering disebut Pembelajaran Kooperatif. Menurut Sugiyanto (2010, 37-41) dalam bukunya model-model Pembelajaran Inovatif bahwa Pembelajaran 
Kooperatif adalah pendekatan pembelajaran yang berfokus pada penggunaan kelompok kecil siswa untuk bekerja sama dalam memaksimalkan kondisi belajar untuk mencapai tujuan belajar. Dalam hal ini guru memberi umpan balik, mengajukan pertanyaan yang menantang dan mengembangkan kegiatan yang beragam, membuat alat bantu belajar sederhana, membuat anak merasa butuh dan memiliki ilmu pengetahuan yang diberikan. Sedangkan dilihat dari sisi siswa dalam pembelajaran, siswa mempunyai keinginan yang aktif bertanya, mengemukakan gagasan, mempertanyakan gagasan orang lain dan gagasan sendiri di kelompoknya. Peserta Didik mampu menguasai keterampilan tepat waktu, berani mencoba, bertanya, mengemukakan isi hati, dan berani mempertanyakan gagasan, sehingga kondisi diri peserta didik selalu terasa nyaman bekerja sama dengan temantemannya dengan penuh semangat belajar.

\section{Supervisi Klinis}

\section{a. Hakikat Supervisi}

Supervisi dalam pengertian tradisional ialah pekerjaan inspeksi melihat dari atas, mengawasi dalam arti mencari kesalahan dengan tujuan untuk diperbaiki. Perilaku supervisi tradisional ini disebut Snooper Vision, yaitu tugas memata-matai untuk menemukan kesalahan. Dari pengertian ini kemudian berkembang, tentang supervisi yang bersifat ilmiah yaitu : (1) sistematis, dilaksanakan secara teratur, berencana dan secara terus - menerus, (2) obyektif, dalam pengertian ini adalah data yang didapat berdasarkan observasi nyata, bukan berdasarkan tafsiran pribadi, (3) menggunakan instrumen yang dapat memberikan informasi sebagai umpan balik untuk mengadakan penilaian terhadap proses pembelajaran. Dalam pengertian lain dikatakan supervisi merupakan kegiatan pembinaan pada personil sekolah pada umumnya dan guru pada khususnya, agar kualitas pembelajaran dapat meningkat. Supervisi dalam hal ini dilakukan pada komponen siswa, guru, kurikulum, prasarana pendidikan, pengelolaan dan lingkungan sekolah. Sebagai dampak dari meningkatnya kualitas pembelajaran, maka diharapkan meningkat pula prestasi belajar siswa dan itu berarti meningkat pula kualitas lulusan sekolah itu. (Arikunto, 2004). Dengan demikian, Supervisi klinis adalah suatu pembimbingan yang bertujuan untuk meningkatkan kinerja guru secara sengaja yang dimulai dari pertemuan awal, observasi di kelas dan pertemuan akhir yang dianalisis secara cermat, teliti dan objektif untuk mendapatkan perubahan perilaku mengajar guru yang diharapkan.

Pada penelitian ini supervisi yang dimaksud adalah kegiatan pengawasan yang dilakukan penulis dalam memberikan bimbingan teknis terhadap tugas pokok guru dalam melaksanaan Pembelajaran berpusat kooperatif oleh guru mata pelajaran masing-masing.

\section{b. Hakikat Supervisi Klinis}

Supervisi Klinis diartikan sebagai bentuk pembinaan kinerja guru dalam mengelola proses pembelajaran. (Sulivan \& Glanz, 2005). Supervisi berasal dari kata "super dan vision ". Super artinya tinggi, atas dan vision artinya melihat, memandang. Suprvision artinya "melihat dari atas". Pengertian tersebut dimaksudkan: orang yang memiliki kedudukan lebih tinggi/atas melihat-mengamati-mengawasi orang yang berada di bawahnya. Misalnya kepala sekolah melihat dan mengamati perilaku guru pada waktu mengajar. Hal itu dilakukan agar kepala sekolah dapat memberikan bimbingan kepada guru untuk melaksanakan tugasnya lebih optimal. Kimball Willer mengemukakan, "Supervision is assistance in the development of better teaching learning situation"."Supervisi adalah 
proses bantuan untuk meningkatkan situasi belajar-mengajar agar lebih baik". Pengertian ini menunjukan bahwa supervisi adalah proses bantuan, bimbingan dan atau pembinaan dari supervisor kepada guru untuk memperbaiki proses pembelajaran. Bantuan, bimbingan atau pembinaan tersebut bersifat profesional yang dilaksanakan melalui dialog untuk memecahkan masalah pembelajaran.

Kepala Sekolah sebagai supervisor membantu dan membina guru sebagai mitra kerjanya agar lebih profesional dalam melaksanakan tugasnya yakni merencanakan dan melaksanakan pembelajaran. Kata yang paling tepat untuk supervisi adalah terprogram untuk mengubah atau memperbaiki perilaku seseorang dalam melaksanakan tugas pokok dan tanggung jawabnya secara profesional. Dengan demikian maka supervisi akademik adalah kegiatan yang terencana, terpola dan terprogram dalam mengubah perilaku guru agar dapat mempertinggi kualitas proses pembelajaran.

Klinis berasal dari kata clinic yang berarti "balai pengobatan atau suatu tempat untuk mengobati berbagai jenis penyakit yang ditangani oleh tenaga yang profesional". Apabila mendengar kata pengobatan maka asosiasi kita adalah pasien datang ke tempat pengobatan untuk mengobati penyakitnya. Orang yang memeriksa dan mengobatinya adalah dokter. Analog dengan itu adalah guru yang mengalami masalah dalam melaksanakan pembelajaran datang kepada kepala sekolah dan untuk berkonsultasi tentang pemecahan masalah yang dihadapinya. Bisa juga kepala sekolah yang datang dan berdialog dengan guru dalam melaksanakan pembelajaran. Kelemahan guru dalam melaksanakan pembelajaran beberapa di antaranya adalah:

a) kurang menguasai bahan ajar sehingga perilaku guru dalam melaksanakan pembelajaran kurang percaya diri,

b) kurang menguasai kelas sehingga siswa kurang terkendali dalam kegiatan belajarnya

c) kurang terampil dalam berbicara sehingga siswa kurang terkendali dalam kegiatan belajarnya,

d) menampilkan sosok yang kurang simpatik sehingga suasana belajar kurang menarik siswa.

Masih banyak gejala lain yang menunjukan kelemahan dan kekurangan guru pada saat melaksanakan pembelajaran. Supervisi klinis berkepentingan dengan upaya memperbaiki kekurangan tersebut. Dengan demikian supervisi klinis diartikan sebagai bantuan profesional yang diberikan kepada guru yang mengalami masalah dalam melaksanakan pembelajaran agar guru tersebut dapat mengatasi masalah yang dialaminya berkaitan dengan proses pembelajaran. Sejalan dengan pengertian di atas Waller berpendapat bahwa supervisi klinis adalah supervisi yang difokuskan pada perbaikan pembelajaran dengan menjalankan siklus yang sistematis dari tahap perencanaan, pengamatan dan analisis yang intensif terhadap proses pembelajaran. Sedangkan menurut Keith Acheson dan Meredith D'Gall:supervisi klinis adalah proses membantu guru memperkecil jurang antar tingkah laku mengajar nyata dengan tingkah laku mengajar yang ideal. Berdasarkan pendapat di atas dapat disimpulkan bahwa yang dimaksud dengan supervisi klinis adalah bantuan profesioanal yang diberikan kepada guru yang mengalami masalah dalam pembelajaran agar guru yang bersangkutan dapat mengatasi masalahnya dengan menempuh langkah yang sistematis mencakup tahap perencanaan, tahap pengamatan dan tahap analisis dan tindak lanjut. Supervisi klinis adalah supervisi yang dilakukan berdasarkan adanya 
keluhan atau masalah dari guru yang disampaikan kepada supervisor. Supervisi klinis adalah bentuk supervisi yang difokuskan pada peningkatan mengajar dengan melalui siklus yang sistematik, dalam perencanaan, pengamatan serta analisis yang intensif dan cermat tentang penampilan mengajar yang nyata, serta bertujuan mengadakan perubahan dengan cara yang rasional.

Ide untuk memberlakukan supervisi klinis bagi guru muncul ketika guru tidak harus disupervisi atas keinginan kepala sekolah sebagai supervisor tetapi atas kesadaran guru datang ke supervisor minta bantuan mengatasi masalahnya. Kepala sekolah sebagai supervisor klinis seyogyanya memiliki pengetahuan dan menguasai penerapan supervisi klinis. Konsep supervisi klinis, mula-mula diperkenalkan dan dikembangkan oleh Morris L. Cogan, Robert Goldhammer, dan Richarct Weller di Universitas Harvard pada akhir dasa warsa lima puluhan dan awal dasawarsa enam puluhan (Krajewski) 1982).

Ada dua asumsi yang mendasari praktik supervisi klinik: Pertama,pembelajaran merupakan aktivitas yang sangat kompleks yang

memerlukan pengamatan dan analisis secara berhati-hati melalui pengamatan dan analisis. Supervisor pembelajaran akan mudah mengembangkan kemampuan guru mengelola proses pembelajaran. Kedua, guru-guru yang profesionalnya ingin dikembangkan dengan pendekatan kolegial daripada cara yang outoritarian (Sergiovanni, 1987).

Supervisi klinis adalah pembinaan kinerja guru dalam mengelola proses pembelajaran (Sullivan \& Glanz,2005). Sedangkan menurut Cogan (1973) Kegiatan pembinaan performansi guru dalam mengelola proses belajar mengajar. Jadi supervisi klinis adalah kegiatan pembinaan guru dalam meningkatkan kinerja atau unjuk kerja dalam proses pembelajaran. Menurut Sergiovanni (1987) ada dua tujuan supervisi klinis: 1) pengembangan profesional dan 2) memotivasi kerja guru dan memperperbaiki proses pembelajaran yang kurang efektif.

Sejalan dengan pengertian di atas maka tujuan umum dari supervisi klinis adalah agar guru memiliki kemampuan untuk memperbaiki dirinya dalam melaksanakan proses pembelajaran. Sedangkan tujuan khususnya adalah : 1) Menyediakan umpan balik yang obyektif terhadap guru, mengenai pembelajaran yang dilaksanakannya. 2) Mendiagnosis dan membantu memecahkan masalah-masalah pembelajaran. 3) Membantu guru mengembangkan keterampilannya menggunakan strategi pembelajaran. 4) Mengevaluasi guru untuk kepentingan promosi jabatan dan keputusan lainnya. 5) Membantu guru mengembangkan satu sikap positif terhadap pengembangan profesional yang berkesinambungan.

Adapun Ciri-Ciri Supervisi Klinis adalah

1. Bantuan yang diberikan bukan bersifat instruksi atau memerintah, tetapi tercipta hubungan manusiawi, sehingga guru-guru memiliki rasa aman.

2. Apa yang akan disupervisi itu timbul dari harapan dan dorongan dari guru sendiri karena dia memang membutuhkan bantuan itu. 
3. Satuan tingkah laku mengajar yang dimiliki guru merupakan satuan yang terintegrasi, sehingga terlihat kemampuan apa, keterampilan apa yang secara spesifik harus diperbaiki.

4. Suasana dalam pemberian supervisi adalah suasana yang penuh kehangatan, kedekatan, dan keterbukaan.

Sedangkan indikator keberhasilan pelaksanaan supervisi klinis adalah :

1) meningkatnya kemampuan guru dalam merencanakan, melaksanakan, dan mengevaluasi proses pembelajaran.,

2) kualitas pembelajaran yang dilaksanakan oleh guru menjadi lebih baik sehingga diharapkan berpengaruh terhadap kualitas hasil belajar yang dicapai siswa,

3) terjalin hubungan kolegial antara kepala sekolah dengan guru dalam memecahkan masalah pembelajaran dan tugas-tugas profesinya. Indikator-indikator tersebut pada hakekatnya merupakan salah satu ciri dari meningkatnya mutu pendidikan di sekolah. Oleh karena itu supervisi klinis merupakan bagian penting dari upaya meningkatkan kinerja sekolah khususnya melalui perbaikan proses pembelajaran. Dalam konteks inilah kepala sekolah perlu melaksanakan supervisi klinis sebagai bagian dari supervisi akademik.

Ada beberapa alasan mengapa supervisi klinis perlu dilaksanakan oleh kepala sekolah dalam rangka membantu guru mengatasi masalah yang dihadapinya dalam pembelajaran. Alasan-alasan tersebut terkait dengan empat aspek sebagai berikut :

\section{a. Kualitas Proses Pembelajaran}

Prestasi belajar siswa dalam berbagai mata pelajaran dipengaruhi oleh dua faktor utama yakni faktor internal dan faktor eksternal. Faktor internal adalah faktor yang bersumber dari diri siswa itu sendiri antara lain : kemampuan, sikap, minat motivasi belajar siswa terhadap mata pelajaran. Faktor eksternal adalah faktor di luar pribadi siswa seperti kurikulum, sarana belajar, lingkungan belajar dan proses pembelajaran yang dilaksanakan guru. Faktor proses pembelajaran menjadi faktor terpenting sebab langsung berhubungan dengan perubahan perilaku siswa. Dalam prakteknya ternyata proses pembelajaran yang dilaksanakan guru belum optimal dalam pengertian tidak membawa hasil yang diinginkan dalam mengubah perilaku siswa. Banyak faktor yang dapat menentukan keberhasilan proses pembelajaran. Faktor -faktor tersebut antara lain: kemampan dan keahlian guru, karakteristik mata pelajaran, sarana dan fasilitas belajar. Oleh sebab itu supervisi klinis dilakukan kepala sekolah perlu memperhatikan faktor-faktor tersebut agar kualitas proses pembelajaran dapat mencapai hasil yang optimal.

\section{b. Profesionalisme Guru}

Jabatan guru adalah jabatan fungsional artinya untuk dapat menyandang jabatan tersebut diperlukan keahlian khusus melalui pendidikan dan pelatihan. Tugas pokok guru adalah merencanakan dan melaksanakan pembelajaran, menilai proses dan hasil belajar serta memberikan bimbingan dan pelatihan. Oleh sebab itu guru perlu menguasai bidang ilmu yang akan menjadi materi pembelajaran serta menguasai teknologi atau strategi 
pembelajaran. Upaya untuk membina dan mengembangkan keahlian tersebut harus terus dilakukan baik oleh guru itu sendiri maupun oleh pihak lain yang bertanggung jawab antara lain kepala sekolah, merupakan bagian dari upaya peningkatan kemampuan profesional guru.

\section{c. Tanggung Jawab Kepala Sekolah}

Kepala sekolah adalah tenaga kependidikan berstatus pegawai negeri sipil yang diangkat dan diberi tugas tanggung jawab dan wewenang oleh pemerintah untuk melaksanakan pengawasan akademik dan pengawasan manajerial pada sekolah yang telah ditunjuk. Pengawasan akademik adalah

menilai dan membina guru dalam aspek-aspek pembelajaran agar dapat meningkatkan hasil belajar siswa. Pengawasan manajerial adalah menilai dan membina guru dan staf sekolah dalam aspek pengelolaan administrasi sekolah agar dapat meningkatkan kinerja sekolah. Oleh sebab itu tanggung

jawab kepala sekolah adalah: a) meningkatkan mutu penyelenggaraan pendidikan di sekolah, dan b) meningkatkan mutu hasil belajar siswa melalui proses pembelajaran yang dilaksanakan guru. Tanggung jawab yang kedua yakni meningkatkan mutu hasil belajar siswa melalui proses pembelajaran yang dilaksanakan guru mengimplikasikan perlunya kepala sekolah melaksanakan supervisi klinis.

\section{d. Peningkatan Mutu Pendidikan}

Pemerintah khususnya kementerian pendidikan nasional telah menetapkan visi pendidikan yakni membentuk insan yang cerdas, kompetitif dan bermartabat dengan empat pilar strategi yakni olah pikir, olah rasa, olah hati dan olah raga. Peraturan pemerintah no. 19 tahun 2005 menetapkan adanya delapan standar nasional pendidikan sebagai rujukan dalam meningkatkan mutu pendidikan nasional. Salah satu standar yang harus dicapai adalah standar kompetensi lulusan. Standar yang erat kaitannya dengan standar isi (kurikulum), standar proses (pembelajaran), standar penilaian dan standar pendidikan dan tenaga kependidikan (guru, kepala sekolah, pengawas sekolah). Dalam pembelajaran tersirat empat standar di atas sebab dalam proses pembelajaran ada: peserta didik (subyek yang belajar), ada bahan ajar (standar isi), ada guru (fasilitator belajar) dan ada penilaian (standar penilaian). Oleh sebab itu kedudukan proses pembelajaran dalam meningkatkan standar mutu pendidikan sangat penting. Supervise klinis yang memfokuskan pada uapaya memperbaiki kualitas proses pembelajaran menjadi upaya yang sangat berarti untuk meningkatkan mutu pendidikan di sekolah.

Tujuan supervisi klinis adalah untuk memperbaiki dan meningkatkan keterampilan mengajar guru di kelas. Dalam hubungan ini supervisi klinis merupakan kunci untuk meningkatkan kemampuan profesional guru. Dalam supervisi klinis, akan langsung dirasakan guru dalam kinerjanya yang mana harus diperbaiki serta dikembangkan. Prosedur supervisi klinis dalam penelitian tindakan sekolah ini berlangsung dalam suatu proses yang berbentuk siklus. Tindakan yang dilakukan ada tiga tahapan, yaitu tahap 
pertemuan pendahuluan, tahap pengamatan dan tahap pertemuan balikan. Tiga tahapan ini dilaksanakan dengan urut berkelanjutan.

\section{B. Kerangka Pikir}

Dalam penelitin ini kerangka pikir penulis adalah guru sebagai penentu keberhasilan pembelajaraan perlu memiliki pengetahuan dan pemahaman tentang standar proses pembelajaran dan pedoman pembelajaran berpusat kooperatif yang telah ditentukan agar dalam melaksanakan pembelajaran lebih bermutu. Untuk itu perlu dilakukan pembimbingan yang lebih intensif oleh Kepala Sekolah sekaligus sebagai peneliti.

Supervisi secara individu dari Kepala Sekolah merupakan model pembimbingan yang langsung mengena pada sasaran yaitu mengetahui tingkatan kemampuan guru dalam melaksanakan pembelajaran. Pada model ini Kepala Sekolah menempatkan diri sebagai teman guru, yang langsung berinteraksi secara interpersonal dalam merencanakan langkah pembelajaran bersama guru. Guru tidak merasa takut kepada Kepala Sekolah, sehingga ia dapat mengemukakan ide-idenya dengan senang hati dan terbuka. Kepala Sekolah aktif memberi contoh dan melakukan simulasi pembelajaran. Guru merasa diperhatikan dan dibantu, sehingga merasa nyaman tersentuh hatinya dalam melaksanakan tugasnya. Akhirnya dalam melaksanakan tugasnya lebih baik, sehingga dapat meningkatkan mutu pembelajaran dan selanjutnya meningkatkan prestasi siswa. Atas dasar itu diduga bahwa dengan supervisi klinis oleh penulis yang dilakukan secara kelompok pada siklus I dan secara individu pada siklus II dapat meningkatkan kemampuan guru dalam melaksanakan pembelajaran dengan model kooperatif, sehingga pada gilirannya meningkatkan prestasi belajar siswa.

Proses pembelajaran yang dilakukan guru membuat kondisi kelas yang menarik bagaikan kelas ini sebagai sumber ilmu pengetahuan bagi peserta didik. Harapan yang diinginkan di samping itu guru selalu berinisiatif serius kepada peserta didik dengan cara membentuk dan membagi kelompok-kelompok kecil, sehingga anak-anak akan lebih bersemangat menerima pelajaran yang disampaikan. Evaluasi hasil belajar dapat tercapai bukan saja tinggi nilai angkanya, tetapi lebih dari itu adalah terciptanya sikap perilaku yang menunjukkan prestasi yang benar-benar menjadi harapan masyarakat.

\section{Hipotesis Tindakan}

Hipotesis tindakan dalam penelitian ini adalah bahwa:

Apabila supervisi klinis dilaksaanakan terhadap guru-guru di SMA negeri 4 Polewali, maka kemampuan menerapkan model pembelajaran kooperatif akan meningkat.

\section{METODE PENELITIAN}

\section{A. Jenis Penelitian}

Metode yang digunakan dalam penelitian ini adalah metode Penelitian Tindakan Sekolah (PTS). PTS merupakan suatu prosedur penelitian yang diadaptasi dari Penelitian Tindakan Kelas (PTK). Penelitian tindakan sekolah merupakan "(1) penelitian partisipatoris yang menekankan pada tindakan dan refleksi berdasarkan pertimbangan rasional dan logis untuk melakukan perbaikan terhadap suatu kondisi nyata; (2) memperdalam pemahaman terhadap tindakan yang dilakukan; dan (3) memperbaiki situasi dan kondisi sekolah / pembelajaran secara praktis" (Depdiknas, 2008 : 11-12). Secara singkat, PTS bertujuan untuk mencari pemecahan permasalahan nyata yang terjadi di 
sekolah-sekolah, sekaligus mencari jawaban ilmiah bagaimana masalah-masalah tersebut bisa dipecahkan melalui suatu tindakan perbaikan.

Pendekatan yang digunakan dalam penelitian tindakan ini ialah pendekatan kualitatif. Artinya, penelitian ini dilakukan karena ditemukan permasalahan kurangnya jumlah guru yang melaksanakan model pembelajaran kooperatif pada proses kegiatan belajar mengajar. Permasalahan ini ditindaklanjuti dengan cara menerapkan sebuah model pembelajaran kooperatif dalam pembelajaarann yang dilakukan oleh Kepala Sekolah, kegiatan tersebut diamati kemudian dianalisis dan direfleksi. Hasil revisi kemudian diterapkan kembali pada siklus-siklus berikutnya. Penelitian ini adalah penelitian tindakan model Stephen Kemmis dan Mc. Taggart (1998) yang diadopsi oleh Suranto (2000; 49) yang kemudian diadaptasikan dalam penelitian ini. Model ini menggunakan sistem spiral refleksi diri yang dimulai dari rencana, tindakan, pengamatan, refleksi, dan perencanaan kembali yang merupakan dasar untuk suatu ancang-ancang pemecahan masalah. Seperti yang diungkapkan oleh Mills $(200 ; 17)$ "Stephen Kemmis has created a well known representation of the action research spiral ...". Penulis menggunakan model ini karena dianggap paling praktis dan aktual.

Kegiatan penelitian tindakan sekolah ini, terdiri atas beberapa tahap, yaitu :

1. Perencanaan

2. Pelaksanaan

3. Pengamatan

\section{Refleksi}

Langkah-langkah penelitian tindakan sekolah dapat digambarkan seperti gambar di bawah ini :

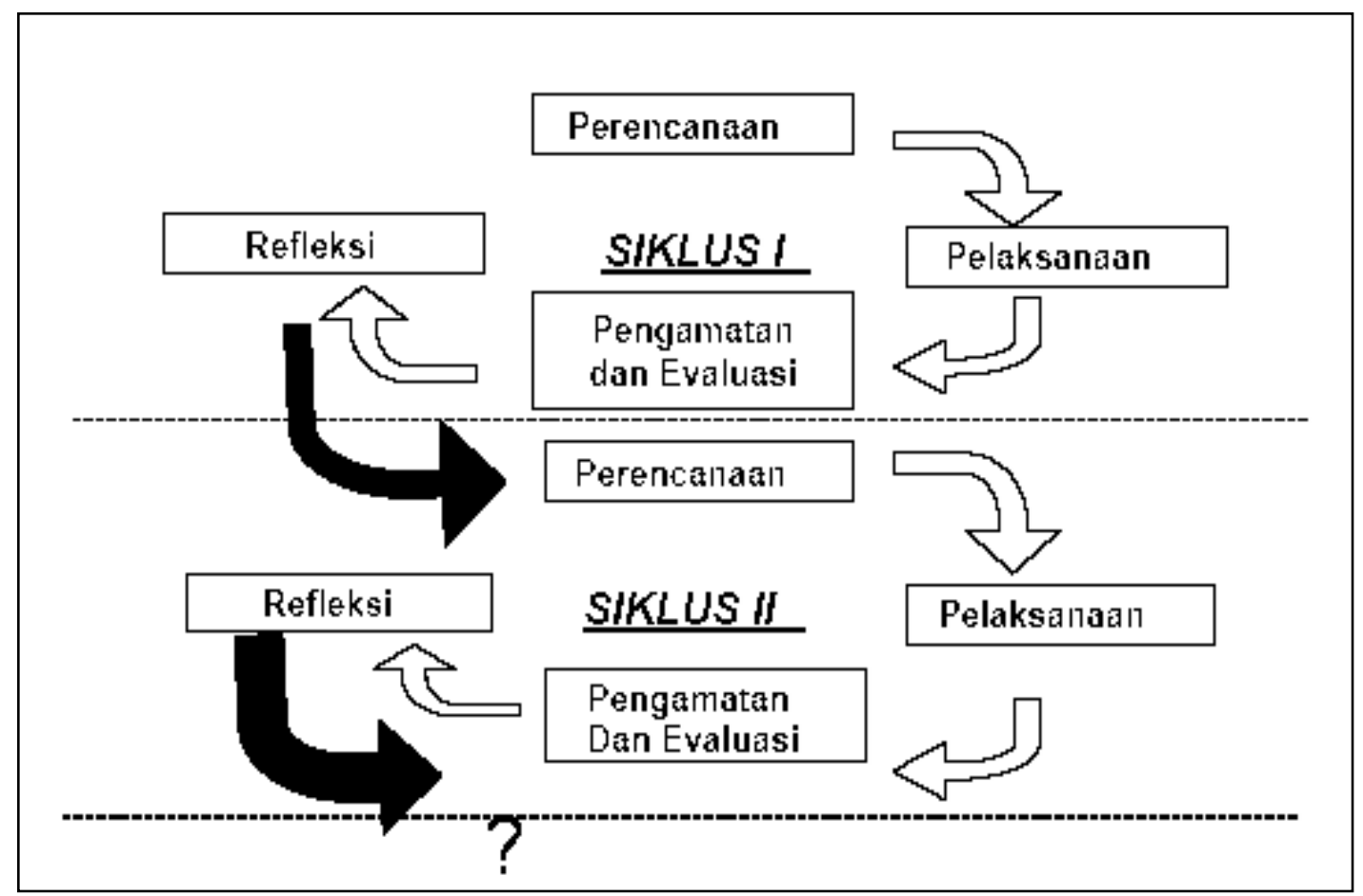




\section{B. Lokasi dan Waktu Penelitian}

1. Lokasi Penelitian : SMA Negeri 4 Polewali Kabupaten Polewali Mandar

2. Waktu Penelitian : bulan Januari s.d Maret 2020

\section{Subjek Penelitian}

Yang menjadi subjek penelitian tindakan sekolah ini adalah guru-guru di SMA Negeri 4 Polewali Kabupaten Polewali Mandar sejumlah 15 orang guru.

\section{Tindakan}

Tindakan yang dilakukan dalam penelitian ini adalah pengecekan RPP guru dalam penerapan pembelajaran kooperatif oleh penulis selaku Kepala Sekolah. Diharapkan dengan supervisi klinis akan terjadi peningkatan dalam penerapan pembelajaran kooperatif dalam proses pembelajaran. Karena keterbatasan waktu, penelitian tindakan sekolah ini hanya dilaksanakan sebanyak dua siklus. Masing-masing siklus dilaksanakan selama satu minggu.

\section{E. Teknik Pengumpulan Data}

Teknik pengumpulan data dari penelitian tindakan sekolah ini adalah melalui data kualitatif yang diperoleh dari observasi, pengamatan, maupun wawancara.

\section{F. Instrumen Penelitian}

Instrumen penelitian yang digunakan dalam penelitian tindakan sekolah ini antara lain adalah lembar pengamatan

\section{G. Teknik Analisis Data}

Analisa data yang digunakan dalam penelitian ini adalah analisis data kualitatif yang bersumber dari data primer maupun empiris. Melalui analisis data ini, dapat diketahui ada tidaknya peningkatan jumlah guru yang menerapkan pembelajaran kooperatif dalam pembelajaran yang merupakan fokus dari penelitian tindakan sekolah ini.

\section{H. Indikator Keberhasilan}

Dalam penelitiaan ini keberhasilan dalam menerapkan pembelajaran kooperatif jika mencapai $75 \%$ 


\section{PEMBAHASAN}

\section{A. Hasil Penelitian}

Penelitian Tindakan Sekolah (PTS) ini dilaksanakan dalam dua siklus. Hal ini dikarenakan keterbatasan waktu yang tersedia, serta dengan dua siklus penulis sudah menganggap cukup untuk menggambarkan ada tidaknya peningkatan jumlah guru yang menerapkan pembelajaran kooperatif dalam kegiatan belajar mengajar.

\section{a. Siklus 1}

Siklus 1 terdiri atas beberapa tahap, yaitu : (1) Perencanaan, (2) Pelaksanaan, (3) Pengamatan dan Evaluasi, dan (4) Refleksi.

\section{Perencanaan}

Perencanaan adalah langkah awal yang dilakukan oleh penulis saat akan memulai tindakan. Agar perencanaan mudah dipahami dan dilaksanakan oleh penulis yang akan melakukan tindakan, rencana tindakan sebagai berikut :

(a) Merumuskan masalah yang akan dicari solusinya. Dalam penelitian ini masalah yang akan dicari solusinya adalah masih banyaknya guru yang tidak menerapkann pembelajaran kooperatif dalam pembelajaran.

(b) Merumuskan tujuan penyelesaian masalah/tujuan menghadapi tantangan/tujuan melakukan inovasi/tindakan. Dalam penelitian ini penulis mengambil rencana untuk melakukan tindakan memberikan penerapan pembelajaran kooperatif pada proses belajar mengajar.

(c) Merumuskan indikator keberhasilan penerapan pembelajaran kooperatif dalam proses belajar mengajar. Indikator keberhasilan penerapan tindakan ini penulis tetapkan sebesar $75 \%$, artinya tindakan ini dinyatakan berhasil bila $75 \%$ guru menerapkan pembelajaran kooperatif dalam proses pembelajaran.

(d) merumuskan langkah-langkah kegiatan penyelesaian masalah/kegiatan menghadapi tantangan/kegiatan melakukan tindakan. Langkah-langkah yang diambil penulis dalam melakukan tindakan antara lain adalah melakukan sosialisasi kepada para guru mengenai penelitian yang akan dilaksanakan, serta menyampaikan tujuan dari penerapan tindakan yang dilakukan oleh penulis. Kepada para guru disampaikan mengenai penerapan pembelajaran kooperatif yang akan diterapkan dalam penelitian ini. Pada siklus pertama ini, akan disampaikan tentang nama-nama guru yang belum menerapkan pembelajaran kooperatif di dalam RPPnya.

\section{Pelaksanaan}

Pelaksanaan penelitian tindakan sekolah ini dilaksanakan melalui beberapa kegiatan, antara lain :

(a) Mengumpulkan RPP guru untuk diidentifikasi penerapan pembelajaaran kooperatif.

(b) Membuat daftar identifikasi guru yang menerapkan pembelajaran kooperatif dan yang belum menerapkan pembelajaran kooperatif 
(c) Melalukan supervisi secara individual terhadap guru-guru baik yang menerapkan pembelajaran kooperatif maupun yang belum menerapkan pembelajaran kooperatif di dalam proses belajar mengajar di kelas.

(d) Melakukan pembimbingan dalam menerapkan pembelajaran kooperatif.

\section{Pengamatan dan Evaluasi}

Pengamatan atau observasi dilakukan oleh penulis dengan menggunakan lembar observasi untuk semua guru.

Pengamatan oleh penulis meliputi:

(a) Pengamatan terhadap RPP guru

(b) penerapan pembelajaran kooperatif

Dari hasil pengamatan serta rekap dari penerapan pembelajaran kooperatif pada proses belajar mengajar dapat dilihat pada tabel berikut :

Tabel 4.1

\section{REKAPITULASI RPP GURU YANG MENERAPKAN PEMBELAJARAN KOOPERATIF SIKLUS I}

\begin{tabular}{|c|c|c|c|c|}
\hline \multirow[t]{2}{*}{ No } & \multirow[t]{2}{*}{ Nama Guru } & \multirow[t]{2}{*}{ Mata pelajaran } & \multicolumn{2}{|c|}{$\begin{array}{c}\text { Penerapan } \\
\text { Pembelajaran } \\
\text { Kooperatif }\end{array}$} \\
\hline & & & yа & tidak \\
\hline 1 & Ika Tandilinting,S.T. & Fisika & ya & \\
\hline 2 & Dr.Muh.Safri,M.M.,M.Pd. & Penjaskes & & tidak \\
\hline 3 & Muh.Rajib,S.Pd. & Sejarah & & tidak \\
\hline 4 & Mudiawati,S.Pd. & Ekonomi & & tidak \\
\hline 5 & Susanti.S.Pd. & $\begin{array}{l}\text { Bahasa } \\
\text { Indonesia }\end{array}$ & & tidak \\
\hline 6 & Andi Haslinda,S.Pd.,M.Si. & Bahasa Inggris & ya & \\
\hline 7 & Rugayyah, S.Pd. & Kimia & & tidak \\
\hline 8 & Ahnur Ahmad, S.Pd. & Geografi & & tidak \\
\hline 9 & Atirah,S.Pd. & Fsika & & tidak \\
\hline 10 & Idawati,S.Pd. & Prakarya & & tidak \\
\hline 11 & Drs. Amos Bollo & $\begin{array}{c}\text { Pendidikan } \\
\text { Seni }\end{array}$ & & tidak \\
\hline
\end{tabular}




\begin{tabular}{|c|l|c|c|c|}
\hline 12 & Nurlinah,S.Pd. & Biologi & & tidak \\
\hline 13 & Nurjannah,S.Pd. & $\begin{array}{c}\text { Pend.Agama } \\
\text { Islam }\end{array}$ & & tidak \\
\hline 14 & Ahmad,S.Pd. & Matematika & & tidak \\
\hline 15 & Nikmawati,S.Pd. & Matematika & & tidak \\
\hline \multicolumn{2}{|c|}{ Jumlah } & $\begin{array}{c}2 \\
(13,33 \%\end{array}$ & $\begin{array}{c}13 \\
(86,67 \%)\end{array}$ \\
\hline
\end{tabular}

Berdasarkan hasil rekapitulasi penerapan pembelajaran kooperatif pada proses pembelajaran diperoleh data, sebanyak $2(13,33 \%)$ orang guru menerapkan pembelajaran kooperatif. Sebanyak $13(86,67 \%)$ orang guru menerapkan pembelajaran kooperatif.

Berdasarkan data di atas dapat ditarik kesimpulan bahwa guru yang menerapkan pembelajaran kooperatif sangat kurang yaitu hanya 2 orang guru. Berdasarkan indikator yang telah ditetapkan bahwa keberhasilan tindakan ini adalah 75\%, atau bila 75\% guru menerapkan pembelajaran kooperatif, jadi penulis berkesimpulan harus diadakan penelitian atau tindakan lagi pada siklus berikutnya atau siklus kedua.

\section{Refleksi}

Setelah selesai satu siklus maka diadakan refleksi mengenai kelemahan atau kekurangan dari pelaksanaan tindakan pada siklus pertama. Refleksi dilaksanakan untuk menentukan tindakan perbaikan pada siklus berikutnya.

Dari hasil refleksi dapat diambil suatu kesimpulan bahwa perlu pembimbingan supervisi klinis dalam menerapkan pembelajaran kooperatif pada siklus pertama.

\section{b. Siklus 2}

Siklus 2 terdiri atas beberapa tahap, sama seperti siklus 1 yaitu :

(1) Perencanaan,

(2) Pelaksanaan,

(3) Pengamatan dan Evaluasi, dan

(4) Refleksi.

\section{Perencanaan}

Dari hasil refleksi, penulis merencanakan untuk melakukan tindakan pembimbingan penyusunan RPP dan pelaksanaaan pembelajaran kooperatif melalui workshop. Dalam workshop akan diundang nara sumber yang dianggap berkompeten dalam pelaksanaan pembelajaran kooperatif.

\section{Pelaksanaan}

Pelaksanaan penelitian tindakan sekolah pada siklus yang kedua ini dilaksanakan melalui beberapa kegiatan, antara lain : 
(a) melaksanakan workshop pembelajaran kooperatif terhadap guru-guru di SMA negeri 4 Polewali.

(b) Menyebarkan lembar pengamatan kepada setiap Ketua Kelas, sesuai dengan banyaknya jumlah rombongan belajar di SMA Negeri 4 Polewali sebanyak 6 rombongan belajar. Dalam lembar pengamatan itu, telah dibuat daftar guru yang mengajar di kelas itu.

(c) Berkoordinasi dengan wakasek kurikulum yang mengamati proses pembelajaran di kelas.

(d) Setelah selesai jam pelajaran, dilakukan rekapitulasi dari hasil pengamatan, baik dari wakasek kurikulum, dari siswa maupun dari penulis.

(e) Melakukan tatap muka dengan guru secara individu dan berdiskusi perihal hasil pengamatan pembelajaran di kelas

\section{Pengamatan dan Evaluasi}

Pengamatan atau observasi dilakukan oleh penulis dengan menggunakan lembar observasi selama satu minggu (satu siklus), untuk semua guru.

Pengamatan oleh penulis meliputi :

(a) Pelaksanaan pembelajaran di kelas

(b) Penerapan pembelajaran kooperatif berdasarkan perencanaan di RPP.

Penulis juga melakukan penilaian dari hasil lembar observasi yang dibagikan kepada pengurus kelas untuk mengamati proses pembelajaran guru di kelas.

Dari hasil pengamatan serta rekap dari tingkat kehadiran guru di kelas pada proses belajar mengajar pada siklus kedua dapat dilihat pada tabel berikut :

Tabel 4.2

REKAPITULASI RPP GURU YANG MENERAPKAN

PEMBELAJARAN KOOPERATIF SIKLUS II

\begin{tabular}{|c|c|c|c|c|}
\hline \multirow[t]{2}{*}{$\mathrm{N}$} & \multirow[t]{2}{*}{ Nama Guru } & \multirow{2}{*}{$\begin{array}{c}\text { Mata } \\
\text { pelajara } \\
\mathrm{n}\end{array}$} & \multicolumn{2}{|c|}{$\begin{array}{c}\text { Penerapan } \\
\text { Pembelajaran } \\
\text { Kooperatif }\end{array}$} \\
\hline & & & ya & tidak \\
\hline 1 & Ika Tandilinting,S.T. & Fisika & ya & \\
\hline 2 & Dr.Muh.Safri,M.M.,M.Pd. & Penjaskes & & tidak \\
\hline
\end{tabular}




\begin{tabular}{|c|l|c|c|c|}
3 & Muh.Rajib,S.Pd. & Sejarah & & tidak \\
\hline 4 & Mudiawati,S.Pd. & Ekonomi & & tidak \\
\hline 5 & Susanti.S.Pd. & $\begin{array}{r}\text { Bahasa } \\
\text { Indonesi } \\
\text { a }\end{array}$ & & tidak \\
\hline 6 & Andi Haslinda,S.Pd.,M.Si. & $\begin{array}{r}\text { Bahasa } \\
\text { Inggris }\end{array}$ & ya & \\
\hline 7 & Rugayyah, S.Pd. & Kimia & & \\
\hline 8 & Ahnur Ahmad, S.Pd. & Geografi & & tidak \\
\hline 9 & Atirah,S.Pd. & Fsika & & \\
\hline 10 & Idawati,S.Pd. & Prakarya & & tidak \\
\hline 11 & Drs. Amos Bollo & $\begin{array}{c}\text { Pendidikan } \\
\text { Seni }\end{array}$ & & tidak \\
\hline 12 & Nurlinah,S.Pd. & Biologi & & \\
\hline 13 & Nurjannah,S.Pd. & Pend.Agama & & Islam \\
\hline 14 & Ahmad,S.Pd. & Matematika & & tidak \\
\hline 15 & Nikmawati,S.Pd. & Matematika & & tidak \\
\hline & & & $6(40 \%)$ & $(60 \%)$ \\
\hline
\end{tabular}

Dari hasil rekapitulasi penerapan pembelajaran kooperatif pada proses pembelajaran diperoleh data, sebanyak 6 orang $(40 \%)$ guru yang telah menerapkan pembelajaran kooperatif di dalam RPPnya, dan 9 orang $(60 \%)$ yang belum menerapkan pembelajaran kooperatif di dalam RPPnya.

Hasil observasi pada siklus pertama dan siklus kedua dapat dilihat ada peningkatan jumlah guru yang menerapkan pembelajaran kooperatif di dalam RPP dan pada proses belajar mengajar di kelas.

\section{Refleksi}

Setelah selesai pelaksanaan tindakan pada siklus kedua maka diadakan refleksi mengenai kelemahan atau kekurangan dari pelaksanaan tindakan pada siklus kedua tersebut.

Berdasarkan hasil observasi dan data yang diperoleh, penulis mengambil kesimpulan bahwa tindakan yang dilaksanakan pada siklus kedua dinyatakan belum berhasil, karena hanya terdapat $6(40 \%)$ guru yang telah menerapkan pembelajaran kooperatif dalam pembelajaran, atau belum mencapai target yang telah ditentukan sebesar $75 \%$. 
Tabel 4.3

\section{KEADAAN GURU SMA NEGERI 4 POLEWALI BERDASARKAN USIA}

\begin{tabular}{|r|l|c|c|}
\hline No & \multicolumn{1}{|c|}{ Nama Guru } & $\begin{array}{r}\text { Mata } \\
\text { pelajaran }\end{array}$ & KETR \\
\hline 1 & Ika Tandilinting,S.T. & Fisika & 35 TAHUN \\
\hline 2 & Dr.Muh.Safri,M.M.,M.Pd. & Penjaskes & 55 TAHUN \\
\hline 3 & Muh.Rajib,S.Pd. & Sejarah & 32 TAHUN \\
\hline 4 & Mudiawati,S.Pd. & Ekonomi & 57 TAHUN \\
\hline 5 & Susanti.S.Pd. & Bhs. Indonesia & 35 TAHUN \\
\hline 6 & Andi Haslinda,S.Pd.,M.Si. & Bahasa Inggris & 42 TAHUN \\
\hline 7 & Rugayyah, S.Pd. & Kimia & 43 TAHUN \\
\hline 8 & Ahnur Ahmad, S.Pd. & Geografi & 28 TAHUN \\
\hline 9 & Atirah,S.Pd. & Fisika & 25 TAHUN \\
\hline 10 & Idawati,S.Pd. & Prakarya & 54 TAHUN \\
\hline 11 & Drs. Amos Bollo & Pendidikan & 59 TAHUN \\
\hline 12 & Nurlinah,S.Pd. & Seni & \\
\hline 13 & Nurjannah,S.Pd. & Biologi & 32 TAHUN \\
\hline 14 & Ahmad,S.Pd. & Pendi.Agama & 43 TAHUN \\
\hline 15 & Nikmawati,S.Pd. & Matematika & 28 TAHUN \\
\hline
\end{tabular}

Berdasarkan tabel 4.3 di atas dan hasil wawancara, ditemukan fakta bahwa kendala guru-guru di SMA negeri 4 Polewali sehingga belum sepenuhnya menerapkan pembelajaran kooperatif adalah sebanyak 6 orang guru (40\%) telah berumur di atas 55 tahun sehingga para guru tersebut tidak ada upaya lagi untuk memperbaiki metode mengajarnya. Di samping itu terdapat 4 orang guru $(26,67)$ yang merupakan guru baru yang belum pernah ikut pelatihan tentang metode mengajar kooperatif. Kondisi guru-guru yang telah memasuki usia menjelang pensiun sangat memengaruhi motivasi untuk berkreasi dan berinovasi dalam memvariasikan metode mengajar. Guru-guru di SMA Negeri 4 Polewali yang berjumlah 6 orang yang berusia 55 tahun ke atas hanya mengajar dengan metode yang telah dilakukan berpuluh-puluh tahun.Fakta lain bahwa guru-guru di SMA negeri 4 Polewali adalah guru-guru yang berasal dari SMA PGRI yang telah ditutup izin operasionalnya. Sebagai sekolah swasta dimana guru-gurunya sebagian besar belum dilatih tentang metode mengajar seperti model kooperatif. Akibat dari hal tersebut, mereka tidak memahami metode lain seperti kooperatif karena tidak membaca dan tidak mau lagi ikut pelatihan-pelatihan yang berkaitan dengan peningkatan profesionalisme sebagai guru. 


\section{PENUTUP}

\section{A. Simpulan}

Berdasarkan hasil penelitian, maka dapat disimpulan bahwa supervisi klinis dapat meningkatkan kemampuan guru menerapkan model pembelajaran kooperatif di SMA negeri 4 Polewali Kabupaten Polewali Mandar semester II tahun pelajaran 2019/2020"

\section{B. Saran-saran}

1. Untuk Kepala Sekolah

a. Agar mengupayakan pelatihan-pelatihan bagi guru yang berkenaan dengan metode mengajar kooperatif.

b. Agar memotivasi guru-guru untuk senantiasa meningkatkan profesionalismenya.

2. Untuk Guru-guru

a. Agar senantiasa berinovasi dalam mengajar

b. Agar dalam mengajar untuk selalu menggunakan media belajar yang tepat.

3. Untuk Pengawas Sekolah

a. Agar para Pengawas Sekolah lebih mengaktifkan supervisi di kelas bukan mencari kesalahan tetapi mengidentifikasi kondisi guru-guru dan mencari solusinya.

b. Agar Pengawas Sekolah melakukan evaluasi dan publikasi tentang hasil dari supervisi di kelas dengan harapan ada upaya perbaikan dan pengambilan kebijakan. 


\section{DAFTAR PUSTAKA}

Depdiknas, 2002.Kamus Besar Bahasa Indonesia. Edisi ketiga, Jakarta: Balai Pustaka

Dirjen PMPTK, 2008a. Pedoman Penelitian Tindakan Sekolah (School Action Research)Peningkatan Kompetensi Supervisi Pengawas Sekolah SMA/SMK. Jakarta: Depdiknas, Ditjen PMPTK.

Dirjen PMPTK, 2008b. Petunjuk Teknis Penelitian Tindakan Sekolah (School Action Research)Peningkatan Kompetensi Supervisi Pengawas Sekolah SMA/SMK. Jakarta: Depdiknas, Ditjen PMPTK.

Depdiknas.2005.UndangUndang RI Nomor 14 Tentang Guru Dan Dosen. Jakarta: Depdiknas.

Depdiknas. 2006. Standar Kompetensi Guru Kelas SD/MI Lulusan $S$ I PGSD. Jakarta: Depdiknas.

Krajewski, RA. 1982. Clinical Supervision: a Conceptual Framwork”, dalam Journal of Research and Development of Indonesian Education. vol. 15

Permendiknas No 41 tahun 2007

Sugiyanto.2010.Model Pembelajaran Inovatif.Surakarta. Yuma Pustaka

Sullivan, S. \& Glanz, J. 2005. Supervision that Improving Teaching Strategies and Techniques. Thousand Oaks, California: Corwin Press.

Suharsimi A. 1998. Prosedur Penelitian Suatu Pendekatan Praktek. Jakarta: Rineka Cipta.

Suharsimi A. 2004. Dasar-dasar Supervisi.akarta.Rineka Cipta

Usman M.U. 2011. Menjadi Guru Profesional. Bandung: PT. Remaja Rosdakarya WJS. Purwadarminto.2000.Depdibud

Sergiovanni, T.J. 1982. Supervision of Teaching. Alexandria: Association for Supervision and Curriculum Development.

Wiles. Kimball.(1956). Supervision for Better School. New Jersey. Printice Hallinc, Engdewood Ciffs 